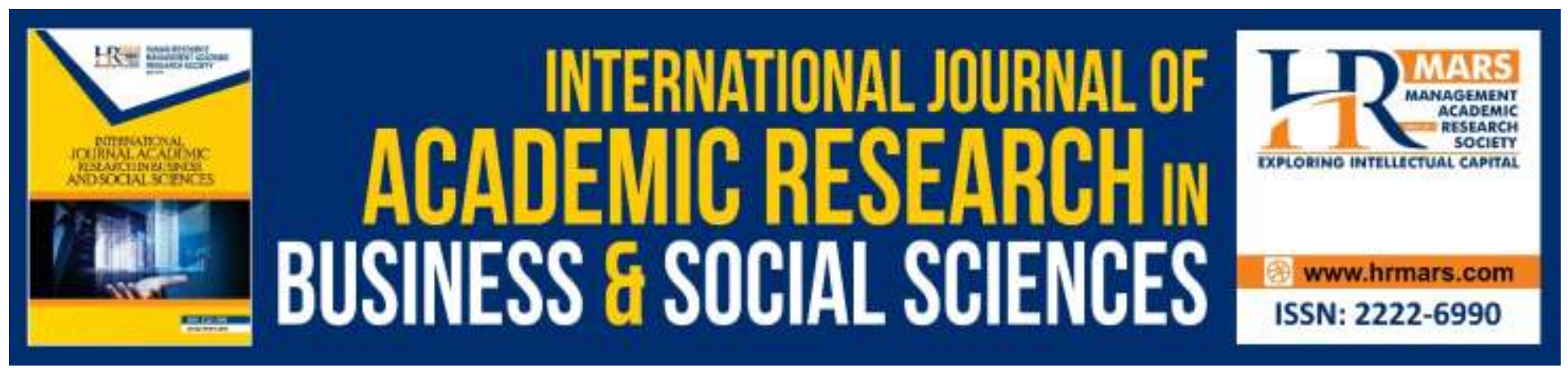

\title{
Analysis of Student Perception on the Quality of Service Provided by a Private Higher Education Institution in East Indonesia
}

Melinda Lydia Nelwan

To Link this Article: http://dx.doi.org/10.6007/IJARBSS/v10-i4/7104

DOI:10.6007/IJARBSS/v10-i4/7104

Received: 11 February 2020, Revised: 02 March 2020, Accepted: 18 March 2020

Published Online: 08 April 2020

In-Text Citation: (Nelwan, 2020)

To Cite this Article: Nelwan, M. L. (2020). Analysis of Student Perception on the Quality of Service Provided by a Private Higher Education Institution in East Indonesia. International Journal of Academic Research in Business and Social Sciences, 10(4), 12-25.

Copyright: ( 2020 The Author(s)

Published by Human Resource Management Academic Research Society (www.hrmars.com)

This article is published under the Creative Commons Attribution (CC BY 4.0) license. Anyone may reproduce, distribute, translate and create derivative works of this article (for both commercial and non-commercial purposes), subject to full attribution to the original publication and authors. The full terms of this license may be seen

at: http://creativecommons.org/licences/by/4.0/legalcode

Vol. 10, No. 4, 2020, Pg. 12 - 25

http://hrmars.com/index.php/pages/detail/IJARBSS

JOURNAL HOMEPAGE

Full Terms \& Conditions of access and use can be found at http://hrmars.com/index.php/pages/detail/publication-ethics 


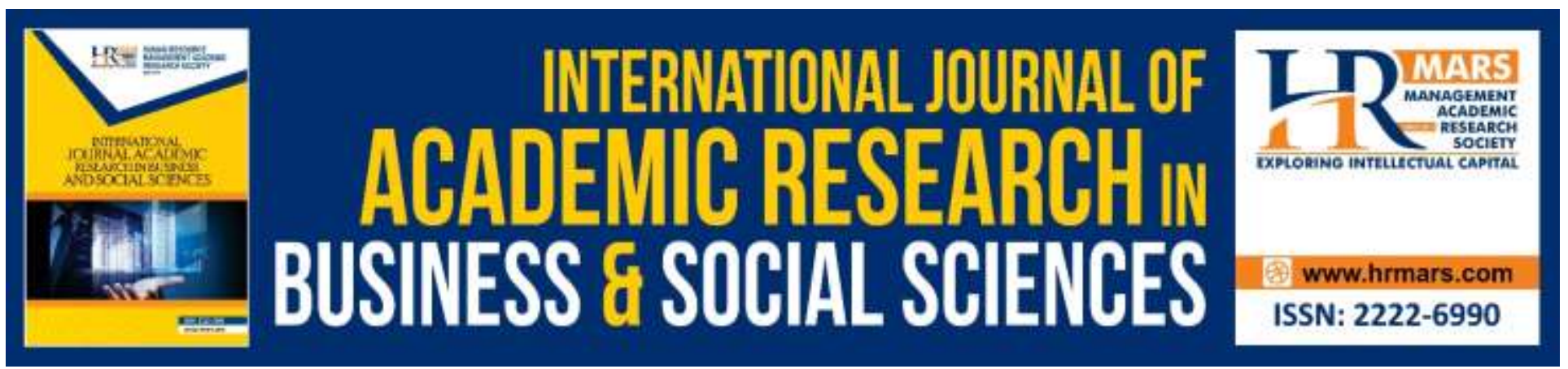

\title{
Analysis of Student Perception on the Quality of Service Provided by a Private Higher Education Institution in East Indonesia
}

\author{
Melinda Lydia Nelwan \\ Faculty of Economics and Business, Universitas Klabat (UNKLAB), Airmadidi, Minahasa Utara - \\ 95371, Sulawesi Utara, Indonesia
}

\begin{abstract}
This research investigated students' perceptions on the quality of service performed by Faculty of Economics and Business at a private higher education institution in East Indonesia, measured by five dimensions in the SERVQUAL (i.e., tangible, reliability, responsiveness, assurance, and empathy). It also investigated whether students' perceptions on the quality of service are different across gender, study program, and length of study. Descriptive analysis and independent-samples $T$ test are used in the examination of data. Adapting and modifying the SERVQUAL model by only focusing on students' perceptions, this study found that overall, students perceived the assurance to have the highest mean score, followed by reliability, empathy, responsiveness, and lastly tangibles. In particular, students perceived the assurance and reliability dimensions to have excellent quality of service, and very good quality of service on empathy, responsiveness, and tangibles. This research found no significant difference on students' perceptions when comparing gender, study program, and length of study. Keywords: Higher Education, Service Quality, Students' Perceptions.
\end{abstract}

\section{Introduction}

Education providers compete to provide better quality education. Indeed, according to Abidin (2015) the quality of higher education is a determinant of global era competitiveness of the nation. Indonesia, in 2015, has at least 121 public owned and 3,104 private owned higher education institutions (Badan Pusat Statistik [Central Agency on Statistics], 2017). Almost half of those institution is located in Java island where the capital city and the central government are. East Indonesia, specifically the Sulawesi, Maluku, and Papua islands, has 482 higher education institutions, 22 of those are public owned and the rest are private owned institutions. However, there is an increasing number of well-known higher education institutions from Java island especially from Jakarta, the capital city of Indonesia, that proactively hunt for new students from other parts of Indonesia including those from East Indonesia. As a consequence, many potential students from this part of Indonesia are now looking for continuing higher education in Jakarta, or other places outside 
INTERNATIONAL JOURNAL OF ACADEMIC RESEARCH IN BUSINESS AND SOCIAL SCIENCES Vol. 10, No. 4, April, 2020, E-ISSN: 2222-6990 @ 2020 HRMARS

of their hometown and even outside of Indonesia. Accordingly, this phenomenon indicates that higher education institutions are competing with each other, across border, claiming to provide better quality of education, hence, those that cannot compete will be left astern.

The quality of service can be determined by several factors. Parasuraman, Zeithaml, and Berry (1985) proposed a SERVQUAL model in which quality is considered through five dimensions which are tangibles, reliability, responsiveness, assurance, and empathy. The SERVQUAL dimensions are widely utilized to gauge the quality of service in many sectors, and particularly in higher education (e.g., Abili, Thani \& Afarinandehbin, 2012; Alhabeeb, 2015; Cerri, 2012; Chui, Ahmad, Bassim \& Zaimi, 2016; Green, 2014; Kanakana, 2014; Rasli, Shekarchizadeh \& Iqbal, 2012; Ulewicz, 2014; Widaryanti, Daryanto \& Fauzi, 2016).

According to several studies (e.g., Cerri, 2012; Chui et al., 2016; Donlagic \& Fazlic, 2015; Green, 2014), in higher education, tangibles refer to physical facilities and infrastructures such as classroom, equipment, teaching materials, etc. Reliability is related to trustworthiness and accuracy in performing services, as well as consistency in practice. Responsiveness is considered as the ability to provide service promptly. Assurance is the knowledge possessed by academic and office staffs in performing their duties, as well as their courtesy towards students. Lastly, empathy is associated with compassionate attention given by the staffs.

Although majority of the research on service quality utilized the expectations - perceptions gap model of the SERVQUAL, the model has some drawbacks as identified by Jain and Aggarwal (2015) based on their review of previous literatures on service quality models. They indicated that the measure of expectations is inadequate because there is no such tool that can measure expectations reasonably. Despite several literatures highlighting the interchangeable use of customer satisfaction and quality (Abidin, 2015), analyzing the gap between expectations and perceptions also create obscurity on whether this model measures quality instead of satisfaction (Jain and Aggarwal, 2015). Indeed, Boulding, Kalra, Staelin, and Zeithaml (1993) as well as Cronin and Taylor (1994) similarly argue that service quality is better gauged by perceptions rather than the gap between expectations and perceptions.

Studies conducted in Indonesia are particularly focused on the quality of service of higher education institutions in Java. For example, Widaryanti et al. (2016) focused on examining students' satisfaction using the SERVQUAL model in a large public university in Java (i.e., Bogor Agricultural University). Another study by Napitupulu et al. (2018) also used the expectations-perceptions gap; however, they only focused on two dimensions: the classroom and the environment, which mainly are comprised of physical aspects of the university. Abidin (2015), in contrast, utilized performance measures which consist of four dimensions (i.e., lecturer, curriculum, administration, facilities and library) in examining different perceptions between students and lecturers in an Islamic public university in Malang, which is also located in Java island. He found that the lecturers' perceptions are higher across all dimensions compared to those of the students.

However, this current study argues that the five dimensions in existing SERVQUAL model would be better in gauging the quality of service of higher education institutions because it covers widely accepted scope of quality dimensions. Moreover, studies on private-owned higher education institutions are very limited. Therefore, this study aimed to examine the students' perception on the quality of service performed by the Faculty of Economic and Business (FEB), at a private higher education institution in East Indonesia, which arguably strives to provide quality service in order not 
INTERNATIONAL JOURNAL OF ACADEMIC RESEARCH IN BUSINESS AND SOCIAL SCIENCES

Vol. 10, No. 4, April, 2020, E-ISSN: 2222-6990 C 2020 HRMARS

to lose potential students due to high competition. This study utilizes the modified SERVQUAL model by only focusing on students' perceptions.

\section{Methodology}

This research was conducted at a private higher education institution in East Indonesia. The objective of this study is to analyze students' perceptions on the quality of service therefore the survey-based method was utilized. This study adapted the questionnaire developed by Donlagic and Fazlic (2015) which is part of the SERVQUAL model proposed by Parasuraman et al. (1985). However, this current study modified the SERVQUAL model, in which it did not examine the gap between expectations and perceptions as suggested by the model due to the arguments posited by Boulding et al. (1993) and Cronin and Taylor (1994). It only focuses on investigating students' perceptions, which is a performance-based measure, to examine the quality of service provided by FEB and whether those perceptions differ by gender, study program, and length of study.

The questionnaire comprises of five dimensions which are tangibles, reliability, responsiveness, assurance, and empathy. There are two parts in the instrument. The first part is the demographic data and the second part is the statements focusing on students' perceptions on the service provided by FEB. Overall, there are 25 items that can be found in the instrument to measure students' perception on the five dimensions of service quality. It utilized a five-point Likert scale (i.e., 1 = strongly disagree, 2 = disagree, 3 = neutral, 4 = agree, and 5 = strongly agree). The responses were mapped using interpretation scale into classification adopted from Vagias (2006). The interpretation table can be seen on Table 1 below.

Table 1. Interpretation Table

\begin{tabular}{ccc}
\hline Likert-Scale & Interpretation scale & Degree of Interpretation \\
\hline 5 & $4.21-5.00$ & Excellent quality \\
4 & $3.41-4.20$ & Very good quality \\
3 & $2.61-3.40$ & Good quality \\
2 & $1.81-2.60$ & Fair quality \\
1 & $1.00-1.80$ & Poor quality \\
\hline
\end{tabular}

The respondents are students at the FEB in this institution. There are 1,247 active students registered at the FEB on the second semester of the school year 2017/2018. It consists of 754 students majoring in accounting, and 493 students majoring in management. Using random sampling among 1,247 FEB students, only 125 students responded to the questionnaire, which represents approximately $10.02 \%$ of the population. However, it is acceptable given that according to Donlagic and Fazlic (2015) sampling rate of at least $5 \%$ can be categorized as relatively large in social science research.

Students' perceptions are collected using the online questionnaire that was distributed to the students. Afterwards, the data analysis was performed by utilizing descriptive analysis and independent-samples T test. 
INTERNATIONAL JOURNAL OF ACADEMIC RESEARCH IN BUSINESS AND SOCIAL SCIENCES

Vol. 10, No. 4, April, 2020, E-ISSN: 2222-6990 @ 2020 HRMARS

\section{Results and Discussions}

\section{Demographic Data}

Demographic analysis on Table 2 shows that a total of 125 students responded to the online survey. Among the respondents 94 (75.2\%) are female and 31 (24.8\%) are male. Table 2 also shows that majority of the respondents are majoring in accounting (i.e., 106 students or $84.8 \%$ ), while the rest are majoring in management (i.e., 19 students or 15.2\%). Most of the respondents are second year students (45.6\%) while the least are first year students (12\%).

Table 2. Demographic Data

\begin{tabular}{|c|c|c|}
\hline Gender & Frequency & Percent \\
\hline Male & 31 & 24.8 \\
\hline Female & 94 & 75.2 \\
\hline Total & 125 & 100 \\
\hline \multicolumn{3}{|l|}{ Panel B: Program } \\
\hline Program & Frequency & Percent \\
\hline Accounting & 106 & 84.8 \\
\hline Management & 19 & 15.2 \\
\hline Total & 125 & 100 \\
\hline \multicolumn{3}{|l|}{ Panel C: Length of Study } \\
\hline Study Year & Frequency & Percent \\
\hline 1st Year & 15 & 12 \\
\hline 2nd Year & 57 & 45.6 \\
\hline 3rd Year & 30 & 24 \\
\hline 4th Year & 23 & 18.4 \\
\hline Total & 125 & 100 \\
\hline
\end{tabular}

\section{Students' Perceptions}

To measure the reliability of items in the questionnaire the Cronbach's alpha test was performed. The results on Table 3 shows that the Cronbach's Alpha of the 25 items in the questionnaire is 0.922 which is higher than 0.7 , the general rule of thumb. Therefore, it can be concluded that the questionnaire is highly reliable to measure students' perceptions on the quality of service provided by FEB.

Table 3. Reliability Test

\begin{tabular}{cc}
\hline Cronbach's Alpha & N of Items \\
\hline 0.922 & 25 \\
\hline
\end{tabular}

Table 4 presents the descriptive statistics on each item in the questionnaire, classified by the five dimensions. Under the dimension of tangibles, Item 3 received the highest mean score (i.e., 4.54) 
INTERNATIONAL JOURNAL OF ACADEMIC RESEARCH IN BUSINESS AND SOCIAL SCIENCES Vol. 10, No. 4, April, 2020, E-ISSN: 2222-6990 @ 2020 HRMARS

wherein students perceived academic staffs appear physically presentable. Item 8 under the category of reliability receives the highest score (i.e., 4.54), indicating that the academic staff are reliable in keeping records of the students. The conduct of academic staff on Item 13 is perceived as the highest quality (i.e., 4.13) by the students, among other items under the responsiveness dimension. The highest score under the dimension of assurance is received by Item 16 (i.e., 4.49) reflecting students' perceptions on the education process. Lastly, among the items in the dimension of empathy, Item 23 (i.e., 4.40) is perceived by the students to have the highest score. This indicates that students perceived the academic staffs are being empathetic when they are available for consultations.

Table 4. Descriptive Statistics of Items

\begin{tabular}{ccccc}
\hline Items & Mean & SD & Min Max \\
\hline
\end{tabular}

\section{$\underline{\text { Tangibles }}$}

1. The faculty utilizes modern and latest equipment in class.

2. The appearance of the physical facilities (e.g., classroom, lab, etc.).

3. Faculty and staffs are well dressed and neat in appearance when in duties.

4. Teaching materials are available to the students and upto-date.

Reliability

5. In general classes are held in accordance with the schedule of lectures and without delays.

6. Office hours of those who handle student affairs (dean, vice dean, head of departments, office secretary) are adequate and in accordance with students' needs.

7. Staff at Faculty of Economy and Business provides support and help to students.

8. Academic staff has precise records of students'

\subsection{8}

2
activities (e.g., presence at lectures, exam results, etc.).

9. Academic staff applies consistent and fair grading criteria.

$\begin{array}{llll}4.37 & 0.71 & 2 & 5\end{array}$

$\begin{array}{llll}3.73 & 0.80 & 2 & 5\end{array}$

$\begin{array}{llll}4.25 & 0.67 & 3 & 5\end{array}$

$\begin{array}{llll}4.54 & 0.62 & 2 & 5\end{array}$

$\begin{array}{llll}4.19 & 0.67 & 2 & 5\end{array}$

10. Students are timely informed about realization of certain activities (e.g., exams, presentation, seminars, etc.).

\section{Responsiveness}

11. Inquiries, requests, and claims of students are handled and resolved timely and promptly.

12. Academic staff conducts themselves in students' best interest.

13. Academic staff pays special attention and provides help to students in resolving their academic problems.

$\begin{array}{llll}3.86 & 0.81 & 2 & 5\end{array}$

$\begin{array}{llll}4.17 & 0.67 & 3 & 5\end{array}$

$\begin{array}{llll}4.13 & 0.75 & 2 & 5\end{array}$


INTERNATIONAL JOURNAL OF ACADEMIC RESEARCH IN BUSINESS AND SOCIAL SCIENCES

Vol. 10, No. 4, April, 2020, E-ISSN: 2222-6990 @ 2020 HRMARS

Assurance

14. Academic staff has the necessary knowledge and skills, and adequate communication skills.

15. Faculty of Economics and Business implements study and educational programs with clear aims for specialization of students.

16. Quality of education process is at a high level.

17. Conduct of staff fills students with confidence.

4.43

4.17

4.49

4.00

4.38

18. Reputation and position of the faculty in the environment is adequate.

19. Academic staff provides professional answers to students' questions.

Empathy

20. Academic staff understands students' academic needs.

21. Academic staff shows positive attitude towards students.

22. Academic staff treats students equally and with respect.

23. Academic staff is available for consultations and is forthcoming towards students.

24. Faculty of Economics and Business values and acknowledges feedback from students for improving processes.

25. Staff is polite, kind and professional in communication with students.

Adapted from: Donlagic and Fazlic (2015).

Overall, the mean on each dimension is shown on Table 5 below, in which the highest mean score is assurance, followed by reliability, empathy, responsiveness, and lastly in tangibles. Using the interpretation table on Table 1, it is indicated that students perceived two of the five dimensions (i.e., assurance and reliability) to be of excellent quality, while the rest (i.e., empathy, responsiveness, tangibles) are very good quality. 
INTERNATIONAL JOURNAL OF ACADEMIC RESEARCH IN BUSINESS AND SOCIAL SCIENCES Vol. 10, No. 4, April, 2020, E-ISSN: 2222-6990 C 2020 HRMARS

Table 5. Overall Means by Dimensions

\begin{tabular}{lcc}
\hline \multicolumn{1}{c}{ Dimensions } & Mean & Degree of Interpretation \\
\hline Tangibles & 3.95 & Very good quality \\
Reliability & 4.24 & Excellent quality \\
Responsiveness & 4.05 & Very good quality \\
Assurance & 4.29 & Excellent quality \\
Empathy & 4.16 & Very good quality \\
\hline
\end{tabular}

Comparing between gender, it can be seen on Table 6 that male students perceived the quality of assurance higher than female students, which is similar to that of responsiveness. However, compared to male students, female students perceived the empathy of the office and academic staff slightly higher. Also the female students perceived the physical aspects as higher. Nonetheless, there is no significant difference between male and female on the perceptions of the five dimensions of quality as can be seen on Appendix 1.

Table 6. Mean Difference by Gender, Study Program, and Length of Study

Panel A: Mean Difference by Gender

\begin{tabular}{|c|c|c|c|c|c|}
\hline Gender & Tangibles & Reliability & Responsiveness & Assurance & Empathy \\
\hline Male & 3.88 & 4.24 & 4.13 & 4.32 & 4.15 \\
\hline Female & 3.97 & 4.24 & 4.03 & 4.28 & 4.17 \\
\hline \multicolumn{6}{|c|}{ Panel B: Mean Difference by Study Program } \\
\hline Program & Tangibles & Reliability & Responsiveness & Assurance & Empathy \\
\hline Accounting & 3.94 & 4.24 & 4.03 & 4.28 & 4.15 \\
\hline Management & 3.99 & 4.22 & 4.21 & 4.33 & 4.19 \\
\hline \multicolumn{6}{|c|}{ Panel C: Mean Difference by Length of Study } \\
\hline Study Year & Tangibles & Reliability & Responsiveness & Assurance & Empathy \\
\hline 1st Year & 4.08 & 4.14 & 4.02 & 4.21 & 4.17 \\
\hline 2nd Year & 3.88 & 4.24 & 3.94 & 4.21 & 4.15 \\
\hline 3rd Year & 3.96 & 4.31 & 4.14 & 4.38 & 4.21 \\
\hline 4th Year & 4.02 & 4.22 & 4.23 & 4.40 & 4.12 \\
\hline
\end{tabular}

Comparing between study program, Table 6 shows that students majoring in management perceived four of the dimensions (i.e., assurance, responsiveness, empathy, and tangibles respectively) higher than those majoring in accounting. Students are usually communicated with their head of study program for their academic matters. The results may arguably indicate that the head of study program of management is more sympathetic to the students compared to his counterpart, given that students perceived the relation dimensions (i.e., assurance, empathy, and responsiveness) to be of higher quality. However, the results of independent-samples $T$ test between study program on Appendix 1 shows that there is no significant difference between students majoring in accounting and management on the perceptions of quality. 
INTERNATIONAL JOURNAL OF ACADEMIC RESEARCH IN BUSINESS AND SOCIAL SCIENCES Vol. 10, No. 4, April, 2020, E-ISSN: 2222-6990 @ 2020 HRMARS

When comparing on the length of study, it can be seen on Table 6 that students perceived the performance of quality dimensions differently. First year students perceived the tangibles higher than their seniors. Third year students perceived reliability and empathy higher than others, and fourth year students perceived responsiveness and assurance higher than their juniors. Students' might put different values on the service they received from FEB across their year of studies at the university. Different students might also encounter different experiences depending on the service they have been exposed to. Nevertheless, there is no significant difference across students from different year level. The results of independent-samples T test can be seen on Appendix 1.

\section{Conclusion}

This study examined the perceptions of students towards the service provided by FEB at a private higher education institution in Indonesia. It utilized a modified SERVQUAL model in which it only focused on measuring perceptions instead of the gap between expectations and perceptions. Using descriptive analysis this study found that among five dimensions of service quality, assurance is perceived to have the highest mean score by students, followed by reliability, empathy, responsiveness, and tangibles. The results indicate that students perceived FEB is able to provide excellent quality of service on the dimensions of assurance and reliability, and very good quality of service on empathy, responsiveness, and tangibles. The independent-samples T test shows that there is no significant difference on students' perceptions of the quality of service provided by FEB when they are compared between gender, study program, and length of study.

The results provide several implications to the university and FEB in particular. First, given that the dimension of tangibles perceived as having lower quality compared to other dimensions, it is recommended to the university to improve quality of physical facilities and infrastructure. Second, the findings also suggest FEB to be more responsive towards claims and suggestions of the students, as well as to be more empathetic towards the students. Third, because assurance and reliability are perceived to have excellent quality, which means that students perceived the academic and office staffs have high capabilities in performing their duties and genuine courtesy towards students, they should be maintained and, to some extent, improved. Selfless service is one of the uttermost principal value that can be practiced by the staff in order to distinctively separate the institution from its competitors.

This study contributes by contextually showing that private university in East Indonesia is capable to provide quality of education services. This indicates that by enhancing the quality of service in terms of physical facilities and study materials, reliability of the faculty and staff, their responsiveness, the quality assurance, as well as empathetic ability of the academic staff, a university may be able to add value to its services and, to some extent, attract more students. Another contribution is specifically attributed to the local government. In order to increase the competitiveness of local universities, local government could provide mechanisms and incentives for these higher education institutions to improve their service quality, since they can also contribute to various systematic development in the area (e.g., human resource, social order, standard of living, etc.).

There are some limitations of this research. First, this research only measures one-time perception of students on the service provided by FEB. It does not measure expectation of the students on the quality of service itself. This is because students have been exposed to the service 
INTERNATIONAL JOURNAL OF ACADEMIC RESEARCH IN BUSINESS AND SOCIAL SCIENCES Vol. 10, No. 4, April, 2020, E-ISSN: 2222-6990 @ 2020 HRMARS

for at least one year. This research argues that measuring expectations at the same time as perceptions will create bias which hinders the ultimate objective of gauging their satisfaction as well as the quality of service provided. In order to reliably measure the quality of service, it is suggested that future study be conducted to measure the expectations of new students (i.e., those who have never been exposed to the service of the FEB or even that of the university) before they receive the service, and subsequently measure their perceptions after they received the service, possibly one semester or even one year after. By then the gap between students' expectations and perceptions can be reliably measured.

Second, this research only utilized and modified the existing SERVQUAL model that measures only five dimensions (i.e., tangibles, reliability, responsiveness, assurance, and empathy). There are other dimensions that can also be added in measuring the quality of service especially in higher education, such as goodwill (i.e., the good reputation of the faculty or the university), research atmosphere, spiritual development programs, extracurricular activities, etc.

Third, it is only limited to the service provided by one faculty, which might not prevail across other faculties in this particular university. Therefore, future study can be done by measuring the overall quality of service in the university.

\section{References}

Abidin, M. (2015). Higher education quality: Perception differences among internal and external stakeholders. International Education Studies, 8(12), 185-191.

Abili, K., Thani, F. N., \& Afarinandehbin, M. (2012). Measuring university service quality by means of SERVQUAL method. Asian Journal on Quality, 13(3), 204-211.

Alhabeeb, A. M. (2015). The quality assessment of the services offered to the students of the college of education at King Saud University using SERVQUAL method. Journal of Education and Practice, 6(30), 82-93.

Badan Pusat Statistik [Central Agency on Statistics]. (2017). Jumlah Perguruan Tinggi, Mahasiswa, dan Tenaga Edukatif (Negeri dan Swasta) di Bawah Kementrian Pendidikan dan Kebudayaan Menurut Provinsi tahun ajaran 2013/2014-2014/2015 [Number of Universities, Students, and Lecturers (State and Private) Under Ministry of Education and Culture by Province, 2013/2014-2014/2015]. Retrieved from: https://www.bps.go.id/statictable/2015/09/14/1839/jumlah-perguruan-tinggi-mahasiswadan-tenaga-edukatif-negeri-dan-swasta-di-bawah-kementrian-pendidikan-dan-kebudayaanmenurut-provinsi-2013-2014-2014-2015.html

Boulding, W., Kalra, A., Staelin, R., \& Zeithaml, V. A. (1993). A dynamic process model of service quality: From expectations to behavioral intentions. Journal of Marketing Research, 30(1), 727.

Cerri, S. (2012). Assessing the quality of higher education services using a modified SERVQUAL scale. Annales Universitatis Apulensis Series Oeconomica, 14(2), 664-679.

Chui, T. B., Ahmad, M. S., Bassim, F. A., \& Zaimi, N. A. (2016). Evaluation of service quality of private higher education using service improvement matrix. Procedia - Social and Behavioral Sciences, 224, 132-140. 
INTERNATIONAL JOURNAL OF ACADEMIC RESEARCH IN BUSINESS AND SOCIAL SCIENCES

Vol. 10, No. 4, April, 2020, E-ISSN: 2222-6990 C 2020 HRMARS

Cronin, J. J., \& Taylor, S. A. (1994). SERVPERF versus SERVQUAL: Reconciling performance-based and perceptions-minus-expectations measurement of service quality. Journal of Marketing, 58, 125-131.

Donlagic, S., \& Fazlic, S. (2015). Quality assessment in higher education using the SERVQUAL model. Management, 20(1), 39-57.

Green, P. (2014). Measuring service quality in higher education: A South African case study. Journal of International Education Research, 10(2), 131-142.

Jain, P., \& Aggarwal, V. S. (2015). Service quality models: A review. BVIMSR's Journal of Management Research, 7(2), 125-136.

Kanakana, M. G. (2014). Assessing service quality in higher education using the SERVQUAL tool. Proceedings of the 2014 International Conference on Industrial Engineering and Operations Management Bali, Indonesia, January 7-9, 2014.

Napitupulu, D., Rahim, R., Abdullah, D., Setiawan, M. I., Abdillah, L. A., Ahmar, A. S., Simarmata, J., Hidayat, R., Nurdiyanto, H., \& Pranolo, A. (2018). Analysis of student satisfaction toward quality of service facility. IOP Conference Series: Journal of Physics, 954, 1-7.

Parasuraman, A., Zeithaml, V. A., \& Berry, L. L. (1985). A conceptual model of service quality and its implications for future research. Journal of Marketing, 49(3), 41-50.

Rasli, A., Shekarchizadeh, A., \& lqbal, M. J. (2012). Perception of service quality in higher education: Perspective of Iranian students in Malaysian universities. International Journal of Academic Research in Management, 1(1), 10-25.

Ulewicz, R. (2014). Application of SERVQUAL method for evaluation of quality of educational services at the university of higher education. Polish Journal of Management Studies, 9, 254263.

Widaryanti, Dayanto, A., \& Fauzi, A. M. (2016). The students' satisfaction oriented: Academic service improvement strategy, department of aquatic resources management, Bogor Agricultural University, Indonesia. Journal of Education and e-Learning Research, 3(3), 98105.

Vagias, W. M. (2006). Likert-type scale response anchors. Clemson International Institute for Tourism \& Research Development, Department of Parks, Recreation and Tourism Management. Clemson University. 
INTERNATIONAL JOURNAL OF ACADEMIC RESEARCH IN BUSINESS AND SOCIAL SCIENCES Vol. 10, No. 4, April, 2020, E-ISSN: 2222-6990 (C) 2020 HRMARS

\section{APPENDIX 1 \\ The Results of Independent Samples T Test}

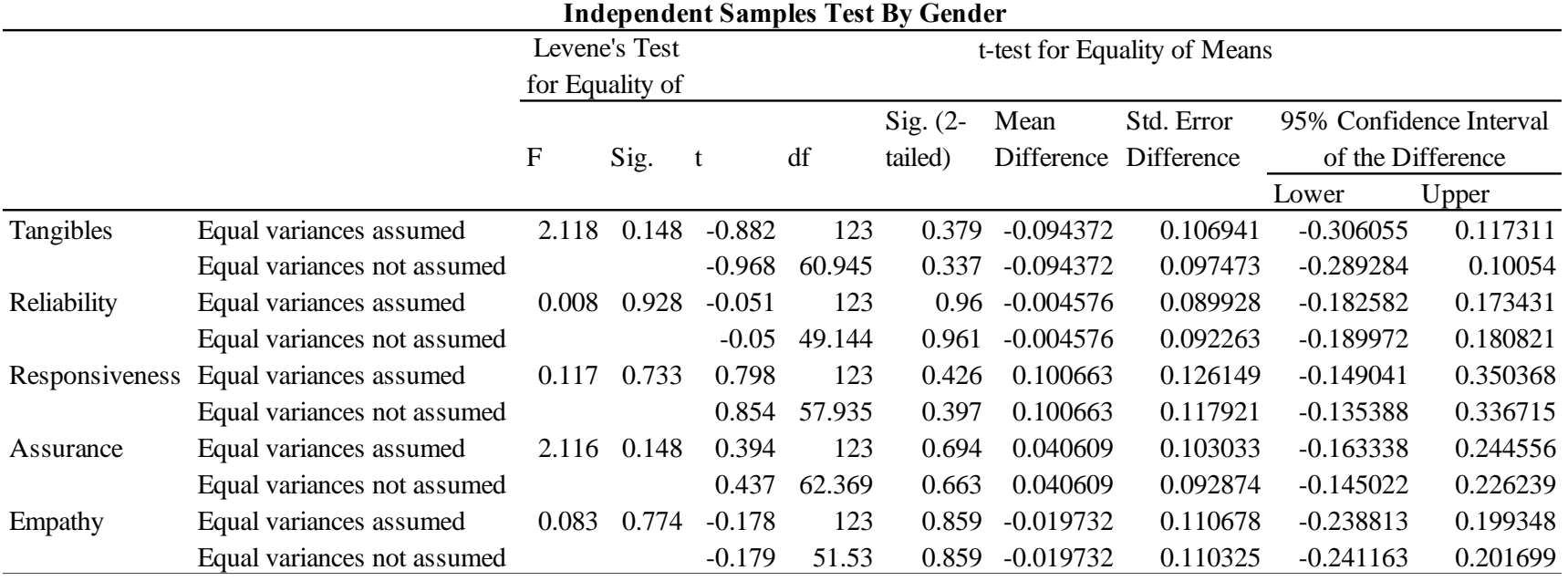

Independent Samples Test by Study Program

\begin{tabular}{|c|c|c|c|c|c|c|c|c|c|c|}
\hline & & \multicolumn{4}{|c|}{$\begin{array}{c}\text { for Equality of } \\
\text { Variances }\end{array}$} & \multicolumn{4}{|c|}{ t-test for Equality of Means } & \\
\hline & & \multirow[b]{2}{*}{$\mathrm{F}$} & \multirow[b]{2}{*}{ Sig. } & \multirow[b]{2}{*}{$\mathrm{t}$} & \multirow[b]{2}{*}{$\mathrm{df}$} & \multirow{2}{*}{$\begin{array}{c}\text { Sig. (2- } \\
\text { tailed) }\end{array}$} & \multirow{2}{*}{$\begin{array}{c}\text { Mean } \\
\text { Difference }\end{array}$} & \multirow{2}{*}{$\begin{array}{l}\text { Std. Error } \\
\text { Difference }\end{array}$} & \multicolumn{2}{|c|}{$95 \%$ Confidence Interval } \\
\hline & & & & & & & & & Lower & Upper \\
\hline \multirow[t]{2}{*}{ Tangibles } & Equal variances assumed & 0.697 & 0.406 & -0.337 & 123 & 0.737 & -0.043446 & 0.128982 & -0.298758 & 0.211866 \\
\hline & Equal variances not assumed & & & -0.366 & 26.853 & 0.717 & -0.043446 & 0.118795 & -0.287256 & 0.200364 \\
\hline \multirow[t]{2}{*}{ Reliability } & Equal variances assumed & 0.263 & 0.609 & 0.226 & 123 & 0.822 & 0.024412 & 0.108149 & -0.189662 & 0.238487 \\
\hline & Equal variances not assumed & & & 0.216 & 24.021 & 0.831 & 0.024412 & 0.113126 & -0.209058 & 0.257883 \\
\hline \multirow[t]{2}{*}{ Responsiveness } & Equal variances assumed & 0.031 & 0.862 & -1.226 & 123 & 0.223 & -0.185369 & 0.151211 & -0.484683 & 0.113944 \\
\hline & Equal variances not assumed & & & -1.292 & 26.087 & 0.208 & -0.185369 & 0.143453 & -0.480194 & 0.109455 \\
\hline \multirow[t]{2}{*}{ Assurance } & Equal variances assumed & 0.370 & 0.544 & -0.444 & 123 & 0.658 & -0.055031 & 0.123913 & -0.300309 & 0.190246 \\
\hline & Equal variances not assumed & & & -0.461 & 25.736 & 0.648 & -0.055031 & 0.119281 & -0.300339 & 0.190276 \\
\hline \multirow[t]{2}{*}{ Empathy } & Equal variances assumed & 0.131 & 0.718 & -0.292 & 123 & 0.771 & -0.038894 & 0.133101 & -0.302360 & 0.224571 \\
\hline & Equal variances not assumed & & & -0.298 & 25.304 & 0.768 & -0.038894 & 0.130582 & -0.307669 & 0.229880 \\
\hline
\end{tabular}

Independent Samples Test Between 1st Year and 2nd Year Students

\begin{tabular}{|c|c|c|c|c|c|c|c|c|c|c|}
\hline & & \multirow{2}{*}{\multicolumn{4}{|c|}{$\begin{array}{c}\text { for Equality of } \\
\text { Variances } \\
\end{array}$}} & \multicolumn{4}{|c|}{ t-test for Equality of Means } & \\
\hline & & & & & & \multirow{2}{*}{$\begin{array}{l}\text { Sig. (2- } \\
\text { tailed) }\end{array}$} & \multirow{2}{*}{$\begin{array}{c}\text { Mean } \\
\text { Difference }\end{array}$} & \multirow{2}{*}{$\begin{array}{l}\text { Std. Error } \\
\text { Difference }\end{array}$} & \multicolumn{2}{|c|}{ 95\% Confidence Interval } \\
\hline & & $\mathrm{F}$ & Sig. & $\mathrm{t}$ & df & & & & Lower & Upper \\
\hline \multirow[t]{2}{*}{ Tangibles } & Equal variances assumed & 0.308 & 0.581 & 1.282 & 70 & 0.204 & 0.201754 & 0.157409 & -0.112189 & 0.515698 \\
\hline & Equal variances not assumed & & & 1.301 & 22.386 & 0.207 & 0.201754 & 0.155118 & -0.119620 & 0.523129 \\
\hline \multirow[t]{2}{*}{ Reliability } & Equal variances assumed & 5.605 & 0.021 & -0.703 & 70 & 0.484 & -0.095322 & 0.135542 & -0.365651 & 0.175008 \\
\hline & Equal variances not assumed & & & -0.558 & 17.412 & 0.584 & -0.095322 & 0.170935 & -0.455314 & 0.264670 \\
\hline \multirow[t]{2}{*}{ Responsiveness } & Equal variances assumed & 2.380 & 0.127 & 0.444 & 70 & 0.658 & 0.080702 & 0.181769 & -0.281824 & 0.443228 \\
\hline & Equal variances not assumed & & & 0.522 & 28.340 & 0.606 & 0.080702 & 0.154577 & -0.235765 & 0.397168 \\
\hline \multirow[t]{2}{*}{ Assurance } & Equal variances assumed & 0.084 & 0.772 & -0.015 & 70 & 0.988 & -0.002339 & 0.153646 & -0.308776 & 0.304098 \\
\hline & Equal variances not assumed & & & -0.015 & 21.555 & 0.988 & -0.002339 & 0.155899 & -0.326042 & 0.321364 \\
\hline \multirow[t]{2}{*}{ Empathy } & Equal variances assumed & 0.549 & 0.461 & 0.110 & 70 & 0.913 & 0.017544 & 0.159926 & -0.301418 & 0.336506 \\
\hline & Equal variances not assumed & & & 0.105 & 20.702 & 0.918 & 0.017544 & 0.167816 & -0.331754 & 0.366842 \\
\hline
\end{tabular}




\section{INTERNATIONAL JOURNAL OF ACADEMIC RESEARCH IN BUSINESS AND SOCIAL SCIENCES Vol. 10, No. 4, April, 2020, E-ISSN: 2222-6990 (C) 2020 HRMARS}

Independent Samples Test Between 1st Year and 3rd Year Students

\begin{tabular}{|c|c|c|c|c|c|c|c|c|c|c|}
\hline & & \multirow{2}{*}{\multicolumn{4}{|c|}{$\begin{array}{l}\text { Levene's Test } \\
\text { for Equality of }\end{array}$}} & \multicolumn{4}{|c|}{ t-test for Equality of Means } & \\
\hline & & & & & & \multirow{2}{*}{$\begin{array}{l}\text { Sig. (2- } \\
\text { tailed) }\end{array}$} & \multirow{2}{*}{$\begin{array}{c}\text { Mean } \\
\text { Difference }\end{array}$} & \multirow{2}{*}{$\begin{array}{l}\text { Std. Error } \\
\text { Difference }\end{array}$} & \multicolumn{2}{|c|}{$95 \%$ Confidence Interval } \\
\hline & & $\mathrm{F}$ & Sig. & $\mathrm{t}$ & df & & & & Lower & Upper \\
\hline \multirow[t]{2}{*}{ Tangibles } & Equal variances assumed & 0.183 & 0.671 & 0.720 & 43 & 0.476 & 0.125000 & 0.173666 & -0.225231 & 0.475231 \\
\hline & Equal variances not assumed & & & 0.731 & 29.336 & 0.470 & 0.125000 & 0.170898 & -0.224351 & 0.474351 \\
\hline \multirow[t]{2}{*}{ Reliability } & Equal variances assumed & 5.446 & 0.024 & -1.054 & 43 & 0.298 & -0.161111 & 0.152900 & -0.469464 & 0.147242 \\
\hline & Equal variances not assumed & & & -0.909 & 19.790 & 0.374 & -0.161111 & 0.177191 & -0.530978 & 0.208755 \\
\hline \multirow[t]{2}{*}{ Responsiveness } & Equal variances assumed & 0.279 & 0.600 & -0.693 & 43 & 0.492 & -0.122222 & 0.176310 & -0.477786 & 0.233341 \\
\hline & Equal variances not assumed & & & -0.733 & 32.665 & 0.469 & -0.122222 & 0.166674 & -0.461455 & 0.217011 \\
\hline \multirow[t]{2}{*}{ Assurance } & Equal variances assumed & 0.160 & 0.691 & -1.060 & 43 & 0.295 & -0.166667 & 0.157254 & -0.483799 & 0.150465 \\
\hline & Equal variances not assumed & & & -1.015 & 25.130 & 0.320 & -0.166667 & 0.164215 & -0.504785 & 0.171451 \\
\hline \multirow[t]{2}{*}{ Empathy } & Equal variances assumed & 0.016 & 0.901 & -0.242 & 43 & 0.810 & -0.044444 & 0.183609 & -0.414728 & 0.325839 \\
\hline & Equal variances not assumed & & & -0.241 & 27.662 & 0.812 & -0.044444 & 0.184723 & -0.423041 & 0.334152 \\
\hline
\end{tabular}

Independent Samples Test Between 1st Year and 4th Year Students

\begin{tabular}{|c|c|c|c|c|c|c|c|c|c|c|}
\hline & & \multicolumn{4}{|c|}{$\begin{array}{l}\text { Levene's Test } \\
\text { for Equality of }\end{array}$} & \multicolumn{4}{|c|}{ t-test for Equality of Means } & \\
\hline & & \multirow[b]{2}{*}{$\mathrm{F}$} & \multirow[b]{2}{*}{ Sig. } & & \multirow[b]{2}{*}{ df } & \multirow{2}{*}{$\begin{array}{l}\text { Sig. (2- } \\
\text { tailed) }\end{array}$} & \multirow{2}{*}{$\begin{array}{c}\text { Mean } \\
\text { Difference }\end{array}$} & \multirow{2}{*}{$\begin{array}{l}\text { Std. Error } \\
\text { Difference }\end{array}$} & \multicolumn{2}{|c|}{$95 \%$ Confidence Interval } \\
\hline & & & & & & & & & Lower & Upper \\
\hline \multirow[t]{2}{*}{ Tangibles } & Equal variances assumed & 2.250 & 0.142 & 0.430 & 36 & 0.670 & 0.061594 & 0.143148 & -0.228724 & 0.351912 \\
\hline & Equal variances not assumed & & & 0.395 & 22.039 & 0.696 & 0.061594 & 0.155764 & -0.261408 & 0.384596 \\
\hline \multirow[t]{2}{*}{ Reliability } & Equal variances assumed & 6.082 & 0.019 & -0.450 & 36 & 0.655 & -0.072947 & 0.161950 & -0.401396 & 0.255502 \\
\hline & Equal variances not assumed & & & -0.406 & 20.565 & 0.689 & -0.072947 & 0.179559 & -0.446843 & 0.300949 \\
\hline \multirow[t]{2}{*}{ Responsiveness } & Equal variances assumed & 0.598 & 0.444 & -1.187 & 36 & 0.243 & -0.209662 & 0.176660 & -0.567945 & 0.148621 \\
\hline & Equal variances not assumed & & & -1.216 & 32.437 & 0.233 & -0.209662 & 0.172433 & -0.560710 & 0.141387 \\
\hline \multirow[t]{2}{*}{ Assurance } & Equal variances assumed & 1.121 & 0.297 & -1.241 & 36 & 0.223 & -0.187440 & 0.151036 & -0.493755 & 0.118876 \\
\hline & Equal variances not assumed & & & -1.160 & 23.495 & 0.258 & -0.187440 & 0.161569 & -0.521280 & 0.146401 \\
\hline \multirow[t]{2}{*}{ Empathy } & Equal variances assumed & 3.271 & 0.079 & 0.307 & 36 & 0.760 & 0.050725 & 0.165137 & -0.284188 & 0.385638 \\
\hline & Equal variances not assumed & & & 0.288 & 23.678 & 0.776 & 0.050725 & 0.176291 & -0.313385 & 0.414834 \\
\hline
\end{tabular}

Independent Samples Test Between 2nd Year and 3rd Year Students

\begin{tabular}{|c|c|c|c|c|c|c|c|c|c|c|}
\hline & & \multicolumn{4}{|c|}{$\begin{array}{l}\text { Levene's Test } \\
\text { for Equality of }\end{array}$} & \multicolumn{4}{|c|}{ t-test for Equality of Means } & \\
\hline & & \multirow[b]{2}{*}{$\mathrm{F}$} & \multirow[b]{2}{*}{ Sig. } & & \multirow[b]{2}{*}{$\mathrm{df}$} & \multirow{2}{*}{$\begin{array}{l}\text { Sig. }(2- \\
\text { tailed) }\end{array}$} & \multirow{2}{*}{$\begin{array}{c}\text { Mean } \\
\text { Difference } \\
\end{array}$} & \multirow{2}{*}{$\begin{array}{l}\text { Std. Error } \\
\text { Difference }\end{array}$} & \multicolumn{2}{|c|}{ 95\% Confidence Interval } \\
\hline & & & & & & & & & Lower & Upper \\
\hline \multirow[t]{2}{*}{ Tangibles } & Equal variances assumed & 0.006 & 0.941 & -0.619 & 85 & 0.537 & -0.076754 & 0.123904 & -0.323108 & 0.169599 \\
\hline & Equal variances not assumed & & & -0.615 & 57.937 & 0.541 & -0.076754 & 0.124777 & -0.326528 & 0.173019 \\
\hline \multirow[t]{2}{*}{ Reliability } & Equal variances assumed & 0.030 & 0.862 & -0.710 & 85 & 0.480 & -0.065789 & 0.092643 & -0.249988 & 0.118409 \\
\hline & Equal variances not assumed & & & -0.722 & 61.862 & 0.473 & -0.065789 & 0.091132 & -0.247969 & 0.116390 \\
\hline \multirow[t]{2}{*}{ Responsiveness } & Equal variances assumed & 1.413 & 0.238 & -1.423 & 85 & 0.158 & -0.202924 & 0.142566 & -0.486384 & 0.080536 \\
\hline & Equal variances not assumed & & & -1.474 & 65.184 & 0.145 & -0.202924 & 0.137625 & -0.477766 & 0.071918 \\
\hline \multirow[t]{2}{*}{ Assurance } & Equal variances assumed & 0.008 & 0.927 & -1.429 & 85 & 0.157 & -0.164327 & 0.114997 & -0.392973 & 0.064318 \\
\hline & Equal variances not assumed & & & -1.476 & 64.631 & 0.145 & -0.164327 & 0.111355 & -0.386742 & 0.058087 \\
\hline \multirow[t]{2}{*}{ Empathy } & Equal variances assumed & 1.317 & 0.254 & -0.496 & 85 & 0.621 & -0.061988 & 0.124965 & -0.310452 & 0.186475 \\
\hline & Equal variances not assumed & & & -0.486 & 55.886 & 0.629 & -0.061988 & 0.127488 & -0.317388 & 0.193412 \\
\hline
\end{tabular}




\section{INTERNATIONAL JOURNAL OF ACADEMIC RESEARCH IN BUSINESS AND SOCIAL SCIENCES Vol. 10, No. 4, April, 2020, E-ISSN: 2222-6990 (C) 2020 HRMARS}

Independent Samples Test Between 2nd Year and 4th Year Students

\begin{tabular}{|c|c|c|c|c|c|c|c|c|c|c|}
\hline & \multicolumn{4}{|c|}{$\begin{array}{l}\text { Levene's Test } \\
\text { for Equality of }\end{array}$} & \multicolumn{4}{|c|}{ t-test for Equality of Means } & \\
\hline & & \multirow[b]{2}{*}{$\mathrm{F}$} & \multirow[b]{2}{*}{ Sig. } & \multirow[b]{2}{*}{$\mathrm{t}$} & \multirow[b]{2}{*}{ df } & \multirow{2}{*}{$\begin{array}{c}\text { Sig. (2- } \\
\text { tailed) }\end{array}$} & \multirow{2}{*}{$\begin{array}{c}\text { Mean } \\
\text { Difference }\end{array}$} & \multirow{2}{*}{$\begin{array}{l}\text { Std. Error } \\
\text { Difference }\end{array}$} & \multicolumn{2}{|c|}{$95 \%$ Confidence Interval } \\
\hline & & & & & & & & & Lower & Upper \\
\hline \multirow[t]{2}{*}{ Tangibles } & Equal variances assumed & 7.071 & 0.010 & -1.138 & 78 & 0.258 & -0.140160 & 0.123124 & -0.385281 & 0.104961 \\
\hline & Equal variances not assumed & & & -1.360 & 62.133 & 0.179 & -0.140160 & 0.103081 & -0.346208 & 0.065888 \\
\hline \multirow[t]{2}{*}{ Reliability } & Equal variances assumed & 0.318 & 0.574 & 0.223 & 78 & 0.824 & 0.022375 & 0.100298 & -0.177303 & 0.222052 \\
\hline & Equal variances not assumed & & & 0.234 & 45.220 & 0.816 & 0.022375 & 0.095655 & -0.170259 & 0.215008 \\
\hline \multirow[t]{2}{*}{ Responsiveness } & Equal variances assumed & 0.918 & 0.341 & -1.871 & 78 & 0.065 & -0.290364 & 0.155205 & -0.599353 & 0.018626 \\
\hline & Equal variances not assumed & & & -2.009 & 47.801 & 0.050 & -0.290364 & 0.144546 & -0.581024 & 0.000297 \\
\hline \multirow[t]{2}{*}{ Assurance } & Equal variances assumed & 0.493 & 0.485 & -1.522 & 78 & 0.132 & -0.185100 & 0.121651 & -0.427288 & 0.057087 \\
\hline & Equal variances not assumed & & & -1.723 & 54.450 & 0.091 & -0.185100 & 0.107414 & -0.400412 & 0.030211 \\
\hline \multirow[t]{2}{*}{ Empathy } & Equal variances assumed & 1.649 & 0.203 & 0.262 & 78 & 0.794 & 0.033181 & 0.126661 & -0.218982 & 0.285344 \\
\hline & Equal variances not assumed & & & 0.289 & 50.901 & 0.774 & 0.033181 & 0.114930 & -0.197562 & 0.263924 \\
\hline
\end{tabular}

Independent Samples Test Between 3rd Year and 4th Year Students

\begin{tabular}{|c|c|c|c|c|c|c|c|c|c|c|}
\hline & & \multirow{2}{*}{\multicolumn{4}{|c|}{$\begin{array}{c}\text { for Equality of } \\
\text { Variances } \\
\end{array}$}} & \multicolumn{4}{|c|}{ t-test for Equality of Means } & \\
\hline & & & & & & \multirow{2}{*}{$\begin{array}{l}\text { Sig. (2- } \\
\text { tailed) }\end{array}$} & \multirow{2}{*}{$\begin{array}{c}\text { Mean } \\
\text { Difference }\end{array}$} & \multirow{2}{*}{$\begin{array}{l}\text { Std. Error } \\
\text { Difference }\end{array}$} & \multicolumn{2}{|c|}{ 95\% Confidence Interval } \\
\hline & & $\mathrm{F}$ & Sig. & $\mathrm{t}$ & $\mathrm{df}$ & & & & Lower & Upper \\
\hline \multirow[t]{2}{*}{ Tangibles } & Equal variances assumed & 5.135 & 0.028 & -0.477 & 51 & 0.636 & -0.063406 & 0.133027 & -0.330468 & 0.203656 \\
\hline & Equal variances not assumed & & & -0.505 & 49.435 & 0.616 & -0.063406 & 0.125579 & -0.315710 & 0.188899 \\
\hline \multirow[t]{2}{*}{ Reliability } & Equal variances assumed & 0.156 & 0.694 & 0.822 & 51 & 0.415 & 0.088164 & 0.107268 & -0.127186 & 0.303515 \\
\hline & Equal variances not assumed & & & 0.828 & 48.770 & 0.412 & 0.088164 & 0.106433 & -0.125746 & 0.302075 \\
\hline \multirow[t]{2}{*}{ Responsiveness } & Equal variances assumed & 0.031 & 0.860 & -0.551 & 51 & 0.584 & -0.087440 & 0.158560 & -0.405763 & 0.230883 \\
\hline & Equal variances not assumed & & & -0.555 & 48.684 & 0.581 & -0.087440 & 0.157415 & -0.403829 & 0.228950 \\
\hline \multirow[t]{2}{*}{ Assurance } & Equal variances assumed & 0.569 & 0.454 & -0.170 & 51 & 0.866 & -0.020773 & 0.122270 & -0.266241 & 0.224695 \\
\hline & Equal variances not assumed & & & -0.174 & 50.697 & 0.862 & -0.020773 & 0.119162 & -0.260036 & 0.218490 \\
\hline \multirow[t]{2}{*}{ Empathy } & Equal variances assumed & 5.787 & 0.020 & 0.662 & 51 & 0.511 & 0.095169 & 0.143868 & -0.193658 & 0.383996 \\
\hline & Equal variances not assumed & & & 0.687 & 50.976 & 0.495 & 0.095169 & 0.138454 & -0.182792 & 0.373130 \\
\hline
\end{tabular}

